\title{
Potential Wetland Screening in Barito Kuala and Banjarmasin as Source of Science Learning
}

\author{
Muhammad Fuad Sya'ban, Arif Sholahuddin, Subhan An'nur, Maulana Khalid Riefani \\ Departement of Mathematics and Natural Science Education \\ Universitas Lambung Mangkurat \\ Banjarmasin, Indonesia \\ fuad.science.edu@unlam.ac.id
}

\begin{abstract}
Learning science utilizes potential diversity of wetlands in South Kalimantan as students learning source.It will be an intermediary for students to learn about themselves and the contextual nature or closely related to everyday life. Decentralization of education brought the Indonesian education toward the development according to the potential of each area, so it needs an effort of educators to explore the diversity of wetlands to be integrated in the process of learning science as a learning source. This is a qualitative research,and the data collection wasconducted through observation and literaturereview. This research was conducted in several areas of Barito Kuala and Banjarmasin in South Kalimantan province. This study covered the area of the river, swamp forests, agricultural land, flora and fauna. The observed variables comprised the characteristics, benefits and categorizing objects including river wetlands, farmland and swamp forests, as well as the diversity of flora and fauna. The data were analyzed by describing, outlining and categorizing the diversity of wetlands that can be considered and integrated in the learning process as learning source.
\end{abstract}

Keywords-Learning source, Learning Science, Wetlands

\section{INTRODUCTION}

Indonesia has a wide diversity of wetlands such as marine, coastal, brackish, rivers, swamps, natural or artificial ponds, and peatlands. The diversity of these wetlands need a "manager" or a candidate manager who is skilled and enthusiastic "preservation" so that it is not only able to be utilized, but also is reliable in environmental conservation in the future. Such managers can be prepared through education. Education is not only preparing students to be able to compete in life, but also able to manage the environment that became the place to live. Therefore, there is an awareness needs by students to respond to the environmental issues.

South Kalimantan has a very diverse and abundant wetland environment. Not only the coast, and sea, South Kalimantan also has peatlands, agricultural lands, swamp forests and streams. According to the data, there are about 400 more rivers located or passing the capital city of Banjarmasin [1]. The diversity of wetlands as well as flora and fauna in South Kalimantan should be immediately noticed by teachers. Therefore, teachers should be able to empower the potential of biological diversity into a learning source in the learning process. Making a wetland potential becomes interrelated in the learning process, it can also be inserted with the character education. It is the character of care and "conservation" on the soul of students and it is necessary to "investigate" that must be done to know what wetland potential learning source to be developed into a part of learning.

\section{METHOD}

This study used mix-method approach. The data collection techniques used direct observation techniques accompanied by literature study. Direct observations were conducted in Barito Kuala and Banjarmasin in South Kalimantan province, covering river areas, swamp forests, agricultural lands, flora and fauna. Data analysis was by describing and categorizing the diversity of wetlands that can be categorized and integrated in the learning process as a source of learning.

\section{RESULT AND DISCUSSION}

The potential learning source in wetlands is summarized and can be seen in Table I. It shows some of the research results for the $7^{\text {th }}$ grade junior high school.

TABLE I. THE SHARING OF LEARNING SOURCES WITH BASIC COMPETENCIES IN SCIENCE LESSONS ON THE $7^{\mathrm{TH}}$ GRADE JUNIOR HigH SCHOOL

\begin{tabular}{|l|l|l|}
\hline \multicolumn{1}{|c|}{ Basic Competencies } & Subject Matter & \multicolumn{1}{c|}{ Learning Sources } \\
\hline $\begin{array}{l}\text { Understand the concept } \\
\text { of measurement of the } \\
\text { various magnitudes that } \\
\text { exist in the self, living } \\
\text { things, and surrounding } \\
\text { physical environment, as } \\
\text { part of the observation, } \\
\text { as well as the importance } \\
\text { of standardized } \\
\text { (standard) standard } \\
\text { formulation in } \\
\text { measurement. }\end{array}$ & $\begin{array}{l}\text { Science and } \\
\text { Objects } \\
\text { along the Barito river, } \\
\text { in the Alalak area. }\end{array}$ \\
\hline $\begin{array}{l}\text { Separate mixtures based } \\
\text { on physical and chemical } \\
\text { properties }\end{array}$ & Substance & \\
& Characteristics & $\begin{array}{l}\text { Farmers in Barito } \\
\text { Kuala practice } \\
\text { separation of rice pulp } \\
\text { with rice grains }\end{array}$ \\
& & $\begin{array}{l}\text { containing rice using a } \\
\text { tool called } \\
\text { "Gumbaan". }\end{array}$ \\
\hline
\end{tabular}




\begin{tabular}{|c|c|c|}
\hline Basic Competencies & Subject Matter & Learning Sources \\
\hline $\begin{array}{l}\text { Know the concept of } \\
\text { energy, various energy } \\
\text { sources, energy from } \\
\text { food, energy } \\
\text { transformation, } \\
\text { respiration, food } \\
\text { digestion system, and } \\
\text { photosynthesis }\end{array}$ & $\begin{array}{l}\text { Energy in the Life } \\
\text { System }\end{array}$ & $\begin{array}{l}\text { Introducing biomass } \\
\text { energy from peat soil, } \\
\text { briquettes from the } \\
\text { bark that are found in } \\
\text { Barito Kuala can be } \\
\text { practicum. }\end{array}$ \\
\hline $\begin{array}{l}\text { Describe the interaction } \\
\text { between living things } \\
\text { and their environment. } \\
\text { Present observation } \\
\text { results to the interaction } \\
\text { of living things with the } \\
\text { surrounding environment }\end{array}$ & $\begin{array}{l}\text { Interaction of } \\
\text { Living Beings and } \\
\text { the Environment }\end{array}$ & $\begin{array}{l}\text { The rivers and swamps } \\
\text { of Barito Kuala and } \\
\text { Banjarmasin can be a } \\
\text { source of learning } \\
\text { about the interaction } \\
\text { of living beings and } \\
\text { the environment. }\end{array}$ \\
\hline $\begin{array}{l}\text { Describe the pollution } \\
\text { and its impact on living } \\
\text { things }\end{array}$ & $\begin{array}{l}\text { The Impact of } \\
\text { Pollution on Life }\end{array}$ & $\begin{array}{l}\text { Observing pollution of } \\
\text { Barito river and rivers } \\
\text { in Banjarmasin } \\
\text { contaminated by wood } \\
\text { waste, water hyacinth } \\
\text { (organic) and plastic } \\
\text { waste (inorganic) }\end{array}$ \\
\hline $\begin{array}{l}\text { Describe the causes of } \\
\text { global warming and its } \\
\text { impact on ecosystems }\end{array}$ & $\begin{array}{l}\text { Global Warming } \\
\text { and Ecosystems }\end{array}$ & $\begin{array}{l}\text { The peat swamp fires } \\
\text { that occur in } \\
\text { Kalimantan, especially } \\
\text { in South Kalimantan } \\
\text { in the Barito Kuala } \\
\text { area at the end of } 2015 \\
\text { can be part of science } \\
\text { learning and become a } \\
\text { source of learning. }\end{array}$ \\
\hline
\end{tabular}

The results of the screening are partially described in Table I. These results can be developed into a module in the science lesson. The module can make students to learn independently. With the development of locally based local advantage modules, it will be able to improve students learning outcomes and provide mastery of the lesson [2][3].

The development of teaching materials and learning tools have been largely done by previous researchers although they are only limited to the feasibility test, and legibility alone, as has been done by [1] who reviewed the study of legibility in the development of ecological materials in wetland areas. The development process in this study produces good teaching materials and can be applied to secondary schools in Kalimantan areas that have wetlands.

This development makes students aware of the wetland environment. Students will also be "knowledgeable" or literate with science because the learning involves local excellence such as wetlands as a source of learning. This is able to make students literate with science which has been undertaken by [4]. He has already undertaken the development of learning tools based on the local excellence of Kalimantan's peatlands. This research produces tools that can give influence to the students of SMP/MTs on the attitude of concern to environment and make students to be more literate to science.

The abovementioneds research has resulted in the importance of local excellence as well as the wetlands in South Kalimantan as part of potential learning source integrated into learning. However, based on the studies that have been done, it cannot be categorized as the suitability of "potential" with the material contained in the school in terms of competence. So, it is necessary to investigate any wetlands potential that can be related to the competence of science subject.

These two new studies are based on some previous research such as research on the development of Subject Specific Pedagogy (SSP) based on local wisdom. It can improve the character (learning motivation and positive attitude) of the science of the 7th grade high junior students in Batam, Kepulauan Riau [5]. Then, another research resulted that there are significant differences between learning using conventional device compared to SSP result of development which was designed based on the implemented learning cycle [6]. This research was about the influence of development of SSP to planting characters of responsibility and creative. Meanwhile, the SSP was developed based on cognitive domains to instill the characters performed [7]. It is also able to improve learning outcomes in the cognitive domain of junior high school students.

Ref. [8] concluded that the a series of the most effective step in identifying the development of learning tools of science is by conducting literature studies, planning, device designing, product designing, validating, limited testing, evaluation and improvement, operational trials, and the last device enhancement. The attainment of the skills-based science learning tools is good, thus providing a significant influence between process skills, scientific attitudes and experimental classroom learning outcomes and controls.

The potential of wetlands in South Kalimantan is the object of learning source including rivers, agricultural lands and swamp forests, flora and fauna. The potential of this wetlands is studied and observed includes the presence of the ecosystem in general, physical properties, chemical properties, benefits, characteristics, diversity of flora and fauna that occupy it, and then linked and grouped according to the subject matter of science.

\section{CONCLUSION}

Screening of wetland potentials in the two districts in the province of South Kalimantan raises the understanding that there are many wetland potentials can be raised as learning source for science learning. The role of a science teacher in learning becomes very important to develop a learning science that brings the wetlands as a source of learning. Some of the potential wetland screening that can be developed as part of learning are such as teaching materials, books or modules. The module can make students learn independently to be used in learning at school or at home independently.

\section{REFERENCES}

[1] A. Winarti, M. Yamin, dan Sarbaini, "Kajian tentang studi keterbacaan dalam pengembangan bahan ajar ekologis di daerah lahan basah," Ethnopedagogy: the proceeding of international seminar ethnopdagogy. Faculty of teacher training and education, Lambung Mangkurat University, Banjarmasin: FKIP UNLAM PRESS, 2015.

[2] M. A. Martawijaya, "Buku fisika peserta didik berbasis kearifan lokal untuk meningkatkan karakter dan ketuntasan belajar", Jurnal Sains dan Pendidikan Fisika, Jilid 10, Nomor 3, Desember 2014, pp. 285- 292. 
[3] Azizahwati, Z. Maaruf, R. M. Yassin, dan E. Yuliani, "Pengembangan modul pembelajaran fisika SMA berbasis kearifan lokal untuk meningkatkan hasil belajar siswa", Prosiding Pertemuan Ilmiah XXIX HFI Jateng \& DIY, Yogyakarta 25 April 2015.

[4] M. F. Sya'ban dan I. Wilujeng, "Pengembangan ssp zat dan energi berbasis keunggulan lokal untuk meningkatkan literasi sains dan kepedulian lingkungan," Jurnal Inovasi Pendidikan IPA, Vol. 2, No. 1, April 2016, pp. 66-75.

[5] Z. Zaid,"Pengembangan Subject Specific Pedagogy Berbasis Kearifan Lokal untuk Meningkatkan Motivasi Belajar dan Sikap Positif terhadap Sains Peserta Didik SMP,” 2014, unpublished.

[6] D. I. Romadoni, "Pengembangan Subject Specific Pedagogy Berbasis Learning Cycle terhadap Penanaman Karakter Tanggung Jawab dan Kreatif Siswa," 2011, Unpublished.
[7] R. Dilliyani, "Pengembangan Subject Specific Pedagogy Berbasis Domain Kognitif Sains untuk Menanamkan Karakater Siswa SMP," Tesis, 2012, Unpublished.

[8] Z. K. Prasetyo, "Pengembangan Perangkat Pembelajaran Sains Terpadu untuk Meningkatkan Kognitif, Keterampilan Proses, Kreatifitas, serta Menerapkan Konsep Ilmiah Peserta Didik SMP," Laporan Penelitian, Yogyakarta: UNY, 2011. 